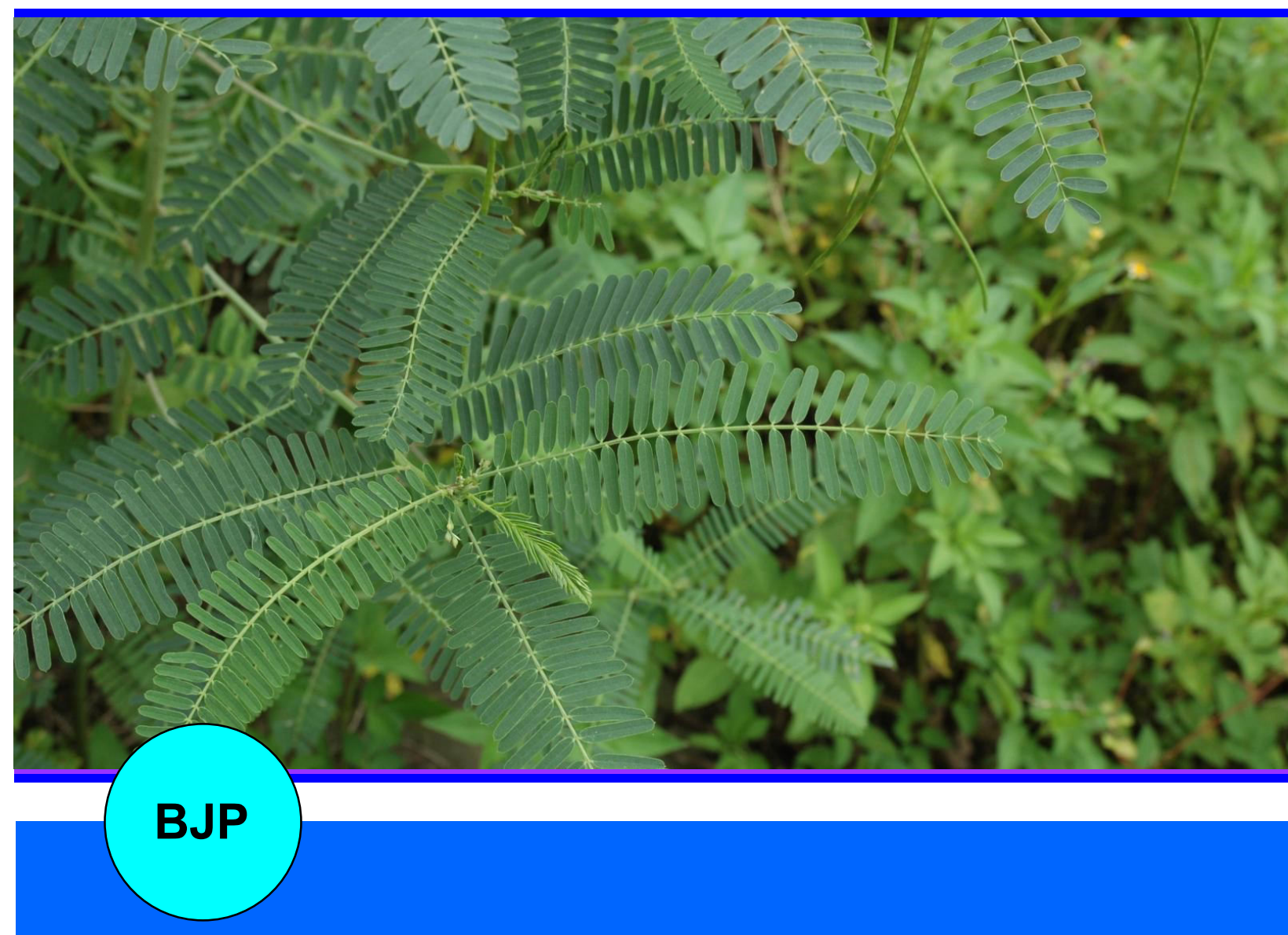

Bangladesh Journal of Pharmacology

Research Article

Aqueous extracts of the leaves of Sesbania sesban reduces development of diabetic nephropathy in streptozotocin-induced diabetic rat 


\title{
Aqueous extracts of the leaves of Sesbania sesban reduces development of diabetic nephropathy in streptozotocin-induced diabetic rat
}

\author{
Ramdas B. Pandhare',3, B. Sangameswaran², Popat B. Mohite ${ }^{1}$ and Shantaram G. \\ Khanage ${ }^{1}$ \\ ${ }^{1}$ Department of Pharmacology, MES College of Pharmacy, Sonai, Newasa, Ahmednagar, Maharashtra 414105 ; \\ ${ }^{2}$ Adesh Institute of Pharmacy and Biomedical Sciences, Bathinda, Punjab; ${ }^{3}$ Department of Pharmacy, Suresh Gyan \\ Vihar University, Jaipur, Rajasthan, India.
}

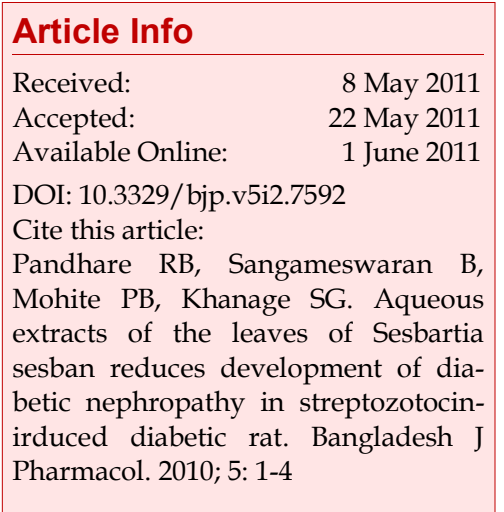

\begin{abstract}
The renal protective effect of the aqueous extract of Sesbania sesban leaves (250 and $500 \mathrm{mg} / \mathrm{kg} /$ day) in streptozotocin-induced diabetic rats were studied. Diabetic rats showed severe hyperglycemia with marked increase in proteinuria and albuminuria. Thye aqueous extract reduced proteinuria, albuminuria, lipid and glycated hemoglobin (HbA1c) deposition in diabetic rats. Histopathology studies on kidneys of diabetic rats revealed severe increase in mesangial cells and matrix of glomeruli with hyaline thickening of some arteriole wall, resulted from selective albuminuria and proteinuria. These changes are inhibited by the extract and glibenclamide. These results suggested that aqueous extract of $S$. sesban has reduced development of diabetic nephropathy in streptozotocin-induced diabetic rats.
\end{abstract}

\section{Introduction}

Diabetic patients may experience some degree of diminution in renal clearance at some stage following onset of the condition (Burrows et al., 2005). Hyperglycemia and a rise in glucose auto-oxidation are responsible for micro- and macro-angiopathy that has been implicated in the induction of an array of diseases including nephropathy (Schnachenberg et al., 2002; Susztak et al., 2006; Hink et al., 2001). Clinical trials suggest that persistent albuminuria is a major biochemical feature for the diagnosis of diabetic nephropathy and has predictive value $70-80 \%$ for the progression of diabetic nephropathy (Leese et al., 1996).

Sesbania sesban (L) Merr. leaves are used in helmintic infection, diabetes, colic and skin diseases (Yusuf et al., 1994). Isolated antitumor principal is kaempferol trisacharide (Upadhyaya et al., 1991). Leaves extract evaluated for antidiabetic potential against streptozotocin-induced diabetes (Pandhare et al., 2011). However, the effect of this herb on diabetic complications is unclear. Therefore, in the present study, the streptozotocin-induced diabetic nephropathy in rats is used to evaluate the renal protective effect of aqueous extract of the leaves of S. sesban.

\section{Materials and Methods}

Collection of plant: The leaves of S. sesban were collected during July 2008 from the Mahatma Phule Krishi Vidyapeeth, Rahuri, Maharashtra, India. The leaves were identified by Dr. P.G. Diwakar, Joint Director, Botanical Survey of India, Pune. A voucher specimen (KSGSS12) has been kept in herbarium, in Botanical Survey of India, Pune Maharashtra.

Chemicals: Streptozotocin was purchased from Sigma Chemical Company, Bangalore. All other chemicals 
used in the experiments were purchased locally (Merck and SD fine Chemicals) and were of analytical grade.

Preparation of aqueous extract: S. sesban leaves were cut into small pieces and were allowed to dry in the shade. About $100 \mathrm{~g}$ of the dried powdered material was extracted at $60^{\circ} \mathrm{C}$ by using soxhlet apparatus for 6 hours using $1 \mathrm{~L}$ of water. The water extract was filtered and evaporated for dryness under vacuum, which yielded a sticky material (yield: $7.5 \% \mathrm{w} / \mathrm{w}$ ). The filtrate was air dried and stored in refrigerator for further use as extract. During experiment the crude extract was diluted with distilled water just before administration to animals (El-Sayed, 1991; Jain, 1968).

Induction of diabetes: Diabetes was induced in male Wistar albino rats aged 2-3 months (180-200 g body weight) by intraperitoneal administration of streptozotocin (single dose of $55 \mathrm{mg} / \mathrm{kg}$ body weight) dissolved in freshly prepared $10 \mathrm{mM}$ citrate buffer, $\mathrm{pH}$ 4.5 (Gupta et al., 2004) after 72 hours rats with marked hyperglycemia (fasting blood glucose $>250 \mathrm{mg} / \mathrm{dL}$ ) were selected and used for the study. All the animals were allowed free access to tap water and pellet diet and maintained at room temperature in plastic cages, as per the guidelines of Institutional Animal Ethics committee.

Experimental design: To investigate the effects of extract, the animals were divided into five groups each consisting of six animals: Normal rats (group 1), diabetic rats (group 2), diabetic rats treated with glibenclamide $0.25 \mathrm{mg} / \mathrm{kg}$ orally (group 3), diabetic rats treated with extract $250 \mathrm{mg} / \mathrm{kg}$ orally (group 4) and diabetic rats treated with extract $500 \mathrm{mg} / \mathrm{kg}$ orally (group 5).

After an overnight fast, extract suspended in distilled water was fed to the group 4 and 5 rats by gastric intubation using a force feeding needle. Group 1 and 2 rats were fed with water alone. Group 3 rats were fed with standard drug glibenclamide. All the animals were administered above treatment daily orally up to 13 weeks.

Metabolic and morphological analysis: After 13 weeks period blood samples were collected from the tail vein after 16 hours fasting. Blood glucose estimation was carried out by glucose oxidase-peroxidase method (Kesari et al., 2005). HbA1c was estimated by the method of Eross et al., 1984). The estimation of serum lipids was carried out by the method of Folch et al., 1957). Estimation of serum cholesterol was carried out by the method of Zlatkis et al., 1953). Serum triglycerides were estimated by the method of Foster and Dunn (Foster et al; 1973) and HDL cholesterol was estimated by the method of Burstein et al., 1970). The VLDL cholesterol was calculated using the formula, TG/5 mg/dL. The serum LDL cholesterol was estimated by the method of Friedwald et al., 1972).
Similarly serum parameters like albumin, creatinine, urea and total protein were also estimated. Individual rats were placed in metabolic cages to obtain 24 hours urine collections and urinary protein, albumin and glucose excretion levels were measured.

Immunohistochemical and immunofluorescent staining: Renal cortexes were fixed in $10 \%$ formaldehyde and embedded in paraffin, and $4 \wedge^{\wedge} \mathrm{m}$ thick sections were prepared. Staining was performed as previously described (Sohn et al., 2007).

Statistical analysis: The results were expressed as mean \pm SEM. The statistical analysis was carried out by using GraphPad Instate version 5. The statistical analysis of the data was carried out using appropriate statistical methods such as Dunnette's multiple comparison test and significant levels are $\mathrm{p}<0.05, \mathrm{p}<0.01$.

\section{Results}

In diabetic rats, body weight was decreased compared with normal rats and did not change compared with rats that treated glibenclamide or extract. Blood glucose and HbA1c levels were significantly increased in diabetic rats $(p<0.01)$. However, no differences in blood glucose and $\mathrm{HbA1c}$ were noted between treated and untreated diabetic rats (Table I).

The serum albumin, creatinine, urea and total protein levels were significantly higher in the untreated diabetic rats compared to those in normal rats. Treatment of the diabetic rats with the aqueous extract produced a significant reduction in the albumin, creatinine, urea and total protein levels (Table II).

\section{Table I}

Effect of S. sesban extract on blood glucose, glycosylated hemoglobin and body weight in diabetic rat

\begin{tabular}{|c|c|c|c|}
\hline Group & $\begin{array}{c}\text { Blood } \\
\text { glucose } \\
(\mathrm{mg} / \mathrm{dL})\end{array}$ & $\begin{array}{c}\mathrm{HbA1c} \\
(\mathrm{mg} / \mathrm{g} \\
\mathrm{Hb})\end{array}$ & $\begin{array}{l}\text { Body } \\
\text { weight } \\
\text { (g) }\end{array}$ \\
\hline Normal rat & $\begin{array}{c}95.2 \\
( \pm 2.0)\end{array}$ & $\begin{array}{c}0.2 \\
( \pm 0.01)\end{array}$ & $\begin{array}{c}185.3 \\
( \pm 0.9)\end{array}$ \\
\hline Diabetic rat & $\begin{array}{l}387.7 \\
( \pm 2.8)\end{array}$ & $\begin{array}{c}0.6 \\
( \pm 0.01)\end{array}$ & $\begin{array}{c}139.0 \\
( \pm 0.8)\end{array}$ \\
\hline $\begin{array}{l}\text { Diabetic rat treat- } \\
\text { ed with glibencla- } \\
\text { mide }(0.25 \mathrm{mg} / \mathrm{kg})\end{array}$ & $\begin{array}{c}115.8 \\
( \pm 1.5)^{\mathrm{a}}\end{array}$ & $\begin{array}{c}0.3 \\
( \pm 0.01)^{\mathrm{a}}\end{array}$ & $\begin{array}{c}138.3 \\
( \pm 1.4)^{\mathrm{a}}\end{array}$ \\
\hline $\begin{array}{l}\text { Diabetic rat treat- } \\
\text { ed with extract } \\
(250 \mathrm{mg} / \mathrm{kg})\end{array}$ & $\begin{array}{c}135.8 \\
( \pm 0.8)^{\mathrm{a}}\end{array}$ & $\begin{array}{c}0.3 \\
( \pm 0.01)^{\mathrm{a}}\end{array}$ & $\begin{array}{c}175.2 \\
( \pm 1.4)^{\mathrm{a}}\end{array}$ \\
\hline $\begin{array}{l}\text { Diabetic rat treat- } \\
\text { ed with extract } \\
(500 \mathrm{mg} / \mathrm{kg})\end{array}$ & $\begin{array}{c}123.7 \\
( \pm 2.0)^{\mathrm{a}}\end{array}$ & $\begin{array}{c}0.3 \\
( \pm 0.00)^{a}\end{array}$ & $\begin{array}{c}173.5 \\
( \pm 1.1)^{\mathrm{a}}\end{array}$ \\
\hline
\end{tabular}

Values are mean \pm SEM from six rats in each group. ${ }^{a} p<0.01,{ }^{b} p<0.05$ 
Table II

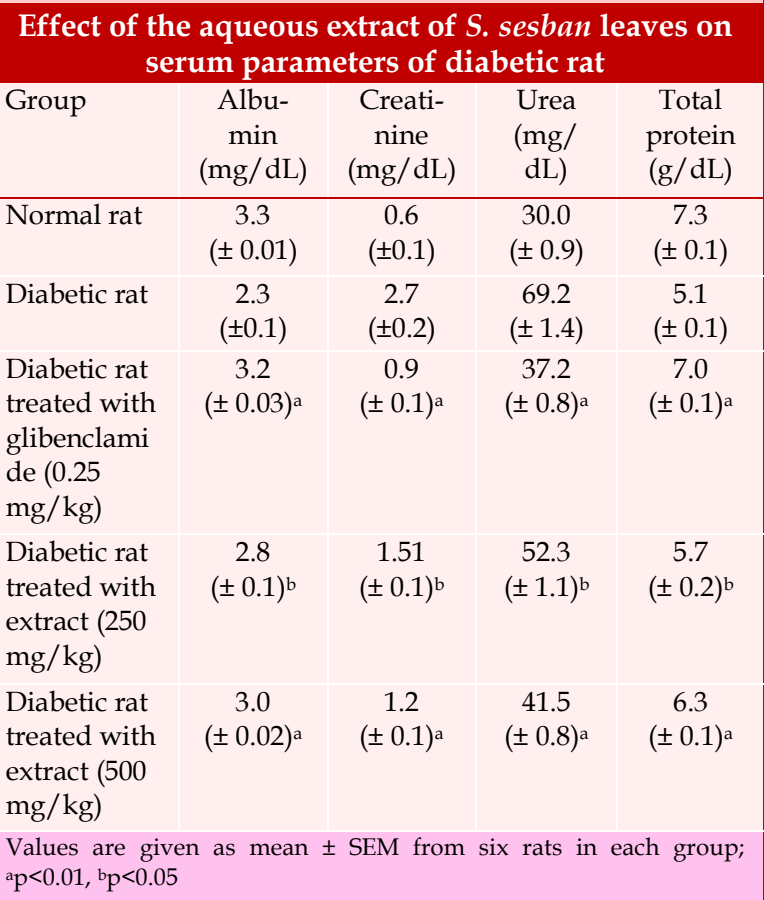

Table III

Effect of the aqueous extract of S. sesban leaves on urine parameters of diabetic rat

\begin{tabular}{|c|c|c|c|}
\hline Group & $\begin{array}{l}\text { Glucose } \\
\text { (mg/ } \\
\mathrm{dL})\end{array}$ & $\begin{array}{l}\text { Albumin } \\
\text { (mg/dL) }\end{array}$ & $\begin{array}{l}\text { Total } \\
\text { protein } \\
(\mathrm{g} / \mathrm{dL})\end{array}$ \\
\hline Normal rat & $\begin{array}{c}0.3 \\
( \pm 0.03)\end{array}$ & $\begin{array}{c}2.2 \\
( \pm 0.04)\end{array}$ & $\begin{array}{c}6.4 \\
( \pm 0.1)\end{array}$ \\
\hline Diabetic rat & $\begin{array}{c}3.8 \\
( \pm 0.1)\end{array}$ & $\begin{array}{c}24.2 \\
( \pm 0.5)\end{array}$ & $\begin{array}{c}25.9 \\
( \pm 0.3)\end{array}$ \\
\hline $\begin{array}{l}\text { Diabetic rat treated } \\
\text { with glibenclamide } \\
(0.25 \mathrm{mg} / \mathrm{kg})\end{array}$ & $\begin{array}{c}1.0 \\
( \pm 0.1)^{\mathrm{a}}\end{array}$ & $\begin{array}{c}4.5 \\
( \pm 0.1)^{\mathrm{a}}\end{array}$ & $\begin{array}{c}7.0 \\
( \pm 0.2)^{\mathrm{a}}\end{array}$ \\
\hline $\begin{array}{l}\text { Diabetic rat treated } \\
\text { with extract }(250 \\
\mathrm{mg} / \mathrm{kg})\end{array}$ & $\begin{array}{c}1.9 \\
( \pm 0.1)^{\mathrm{b}}\end{array}$ & $\begin{array}{c}8.4 \\
( \pm 0.1)^{\mathrm{b}}\end{array}$ & $\begin{array}{c}10.0 \\
( \pm 1.2)^{\mathrm{b}}\end{array}$ \\
\hline $\begin{array}{l}\text { Diabetic rat treated } \\
\text { with extract ( } 500 \\
\mathrm{mg} / \mathrm{kg})\end{array}$ & $\begin{array}{c}1.6 \\
( \pm 0.1)^{\mathrm{a}}\end{array}$ & $\begin{array}{c}7.3 \\
( \pm 0.1)^{\mathrm{a}}\end{array}$ & $\begin{array}{c}8.9 \\
( \pm 0.1)^{\mathrm{a}}\end{array}$ \\
\hline
\end{tabular}

The urinary glucose, albumin and total protein levels were significantly higher in the untreated diabetic rats compared to those in normal rats. Treatment of the diabetic rats with the extract produced a significant reduction in the albumin, creatinine, urea and total protein levels (Table III).

Histopathological changes in kidneys of normal, diabetic untreated, diabetic treated with standard drug glibenclamide and aqueous extract were studied.
Diabetic untreated rats renal tissue when compared to other treated group revealed severe increase in mesangial cells and matrix of glomeruli. Hyaline thickening of some arteriole wall was also noted. With treatment with glibenclamide and aqueous extract, these pathologic changes were improved.

\section{Discussion}

The present study shows the effects of aqueous extract of the leaves of $S$. sesbania on glycemic and renal protection in streptozotocin-induced diabetic rats. The extract showed a dose-dependent effect on fasting blood glucose level. The capacity to decrease the elevated blood glucose to normal level is an essential trigger for the liver to revert to its normal homeostasis during experimental diabetes. The possible mechanism by which aqueous extract exerts its hypoglycemic action in diabetic rats may be due to potentiating the insulin release, since the percentage fall in blood glucose levels was very significant $(p<0.01)$ at $500 \mathrm{mg} /$ $\mathrm{kg}$. Lower levels of total hemoglobin observed in diabetic rats might be due to the increased formation of $\mathrm{HbA1c}$. In uncontrolled or poorly controlled diabetes, there is an increased glycosylation of a number of proteins including hemoglobin and crystalline of lens (Alberti et al., 1982). HbA1c was found to increase in patients with diabetes mellitus and the amount of increase was directly proportional to the fasting blood glucose levels (Pari et al., 2002). Therefore, measurement of $\mathrm{HbA} 1 \mathrm{c}$ is supposed to be very sensitive index for glycemic control. Treatment with aqueous extract showed a significant decrease in the glycated hemoglobin levels, which could be due to an improvement in insulin secretion. Induction of diabetes with streptozotocin is associated with the characteristic loss of body weight, which is due to increased muscle wasting (Swanston et al; 1990), and due to loss of tissue proteins (Chatterjea et al; 1976). Diabetic rats treated with the aqueous extract showed an increase in body weight when compared to the untreated diabetic rats which may be due to its protective effect in controlling muscle wasting i.e. reversal of gluconeogenesis and may also be due to the improvement in glycemic control.

This study shows that aqueous extract reduced the development of diabetic nephropathy via reductions in serum albumin, creatinine, urea and total protein and urine glucose, Albumin and total protein levels in streptozotocin-induced diabetic rats. Hence, our current study confirmed that aqueous extract-treated diabetic rats showed significant improvement in renal functions such as proteinuria and albuminuria. It seems likely that the treatment with aqueous extract is effective for treatment for diabetic nephropathy due to inhibition of proteinuria and albuminuria could be a valuable 
therapeutic approach in diabetic nephropathy.

\section{Acknowledgement}

The authors thank to Principal Dr. VK Deshmukh, M.E.S. College of Pharmacy, Prashant Patil Gadakh Secretory, Mula Education Society, Sonai and Department of Pharmacy, Suresh Gyan Vihar University, Jaipur, Rajasthan, India for encouragement and availing of the laboratory facilities during the course of investigation.

\section{References}

Akhtar MS, Ali MR. Study of antidiabetic effect of a compound medicinal plant prescription in normal and diabetic rabbits. J Pak Med Assoc. 1984; 34: 239-44.

Alberti KGMM, CM. Press, The biochemistry and the complications of diabetes In: Complications of diabetes. Keen $\mathrm{H}$, Jarrett J (eds), vol. 43. Edward Arnold Ltd., London, 1982, pp 231-70.

Burrows NR, Wang J, Geiss LS, Venkat Narayan KM, Engelgau MM. Incidence of end-stage renal disease among persons with diabetes e United States, 1990-2002. MMWR Weekly. 2005; 54: 1097-100.

Burstein M, Scholnichk HR, Morin R. Rapid method for the isolation of lipoproteins from human serum by precipitation with polyanions. J Lipid Res. 1970; 11: 583-95.

Chatterjea MN, Shinde R. Diabetes mellitus: Textbook of medical biochemistry. $5^{\text {th }}$ ed. New Delhi, Jaypee Brothers Medical Publishers Ltd., 1976.

El-Sayed NH. A rare kaempferol trisaccharide anti-tumor promoter from Sesbania sesban. Pharmazie 1991; 46, 679-80.

Eross J, Kreutzman D, Jimenez M, Keen R, Rogers S, Cowell C, Vines R, Silink M. Colorimetric measurement of glycosylated protein in whole blood cells plasma and dried blood. Ann Clin Biochem. 1984; 21: 519-22.

Folch J, Lees M, Solane SGH. A simple method for isolation and purification of total lipids from animal tissues. J Biol Chem. 1957; 26: 497-509.

Foster JB, Dunn RT. Stable reagents for determination of serum triglycerides by colorimetric Hantzsch condensation method. Clin Chem. 1973; 19: 338-40.

Friedwald WT, Levy RI, Fredrickson DS. Estimation of the concentration of LDL-cholesterol in plasma without the use of the preparative ultracentrifuge. Clin Chem. 1972; 18: 499502.
Gupta S, Kataria M, Gupta PK, Murganandan S, Yashroy RC. Protective role of extracts of neem seeds in diabetes caused by streptozotocin in rats. J Ethnopharmacol. 2004; 90: 185-89.

Hink U, Li H, Mollnau H. Mechanisms underlying endothelial dysfunction in diabetes mellitus. Circ Res. 2001; 88: e14-22.

Jain SR. Hypoglycemic principal in the Musa sapeintum and its isolation. Planta Medica. 1968; 1: 43-47.

Kesari AN, Gupta RK, Watal G. Hypoglycemic effects of Murraya koenigii on normal and alloxan diabetic rabbits. J Ethnopharmacol. 2005; 97: 247-51.

Khare CP. Indian medicinal plants: An illustrated dictionary. Springer, Verlag Berlin, 2007, p 601.

Leese GP, Savage MW, Chattington PD, Vora JP. The diabetic patient with hypertension. Postgraduate Med J. 1996; 72: 263 -68 .

Pari L, Saravanan G. Antidiabetic effect of Cogent db, a herbal drug in alloxan-induced diabetes mellitus. Comp Biochem Physiol. C: Pharmacol Toxicol Endocrinol. 2002; 131: 19-25.

Ramdas B. Pandhare, B. Sangameswaran, Popat B. Mohite, Shantaram G. Khanage. Antidiabetic activity of aqueous leaves extract of Sesbania sesban (L) Merr. in streptozotocininduced diabetic rats. 2011; 3: 37-43.

Schnachenberg CG. Oxygen radicals in cardiovascularerenal disease. Curr Opin Pharmacol. 2002; 2: 121-25.

Sohn EJ, Kim CS, Kim YS, Jung DH, Jang DS, Lee YM, Kim JS. Effects of magnolol (5,50-diallyl-2, 20-dihydroxybiphenyl) on diabetic nephropathy in type 2 diabetic Goto-Kakizaki rats. Life Sci. 2007; 80: 468-75.

Susztak K, Raff AC, Schiffer M. Glucose-induced reactive oxygen species cause apoptosis of podocytes and podocyte depletion at the onset of diabetic nephropathy. Diabetes 2006; 55: 225-33.

Swanston-Flatt SK, Day C, Bailey CJ, Flatt PR. Traditional plant treatment for diabetes: Studies in normal and streptozotocin diabetic mice. Diabetologia 1990; 33: 462-64.

Upadhyaya JS, Singh SP. Chromatographic studies of oxidation products of lignin from Sesbania sesban. Cellul Chem Technol. 1991; 25: 219-26.

Yusuf M, Chowdhury JU, Wahab MA, Begum J. Medicinal plants of Bangladesh. BCSIR, Dhaka, Bangladesh. 1994, p 223.

Zlatkis A, Zak B, Boyle AJ. A new method for the direct determination of serum cholesterol. J Lab Clin Med. 1953; 41: 48692.

\footnotetext{
Author Info

Ramdas B. Pandhare (Principal contact)

I e-mail: ramdaspandhare83@rediffmail.com
} 